\title{
Contact-Induced Emigration of Potato Leafhopper (Homoptera: Cicadellidae) from Alfalfa-Forage Grass Mixtures
}

\author{
A. L. RODA, ${ }^{1}$ D. A. LANDIS, AND J. R. MILLER \\ Department of Entomology and Pesticide Research Center, Michigan State University, East Lansing, MI 48824
}

\begin{abstract}
Environ. Entomol. 26(4): 754-762 (1997)
ABSTRACT Studies were conducted to evaluate the mechanisms leading to increased potato leafhopper, Empoasca fabae (Harris), emigration from alfalfa-forage grass mixtures. A laboratory behavioral bioassay was used to measure daily emigration rates of adult leafhoppers from alfalfa, Medicago sativa L.; smooth bromegrass, Bromus inermis Leyss.; orchardgrass, Dactylis glomerata L.; and timothy, Phleum pratense L., alone and in 1:1 mixtures of each grass with alfalfa. Emigration was $\approx 9$-fold greater from pure bromegrass and orchardgrass treatments versus alfalfa alone, and $\approx 5$-fold greater than from mixtures of alfalfa and each grass species. In a 2nd experiment, alfalfa and forage grasses were separated by a barrier permeable to plant volatiles. Only $31 \%$ of the potato leafhoppers placed on alfalfa adjacent to either alfalfa or grass emigrated. However, when introduced to the side containing a forage grass, $<85 \%$ of the leafhoppers emigrated, regardless of adjacent plant. Thus, stimuli obtained from physical contact with the grass versus grass volatiles alone were required to elicit emigration. Observations of potato leafhoppers on single plants of smooth bromegrass, orchardgrass, and alfalfa revealed that individuals fed on all 3 species; however, the frequency and duration of probing differed as did mean residency time ( $10.7 \mathrm{~h}$ alfalfa, $7.5 \mathrm{~h}$ bromegrass, 5.9 $\mathrm{h}$ orchardgrass). These experiments suggested that physical contact is necessary to elicit emigration from grasses. By increasing emigration, alfalfa-forage grass mixtures may reduce potato leafhopper damage to alfalfa. Additionally, intercropping with forage grasses may lower the number of feeding bouts on alfalfa and reduce subsequent hopperburn.
\end{abstract}

KEY WORDS Empoasca fabae, intercropping, behavior, emigration, alfalfa, forage grasses

THE POTATO LEAFHOPPER, Empoasca fabae (Harris), is a polyphagous, highly mobile, insect that inflicts severe economic damage on alfalfa, Medicago sativa L. (Bames and Shaeffer 1985). E. fabae migrates annually from southern states, and colonizes alfalfa before 2 nd cutting in the north central United States (Carlson et al. 1991, Taylor and Shields 1995). Because of their small size and mobility, potato leafhoppers are frequently not detected in alfalfa before visual signs of injury, "hopperburn," has become apparent (Ball 1919, Byers et al. 1977, Faris et al. 1981). Potato leafhopper feeding causes reductions in dry matter (Hower and Flinn 1986, Hutchins and Pedigo 1990), plant height (Nielsen et al. 1990), crude protein (Kindler et al. 1973, Nielsen et al. 1990), and carotene (Kindler et al. 1973). The process by which potato leafhoppers feed and the type of plant tissues they select have been implicated in causing hopperburn and the corresponding losses in yield and quality (Backus and Hunter 1989, Hunter and Backus 1989, Nielsen et al. 1990). Factors that may result

\footnotetext{
${ }^{1}$ Current address: New York Agricultural Experiment Station, Comell University, Barton Lab-Department of Entomology, Geneva, NY 14456.
}

in fewer probes made on alfalfa would conceivably reduce the extent of injury.

The presence of various grasses within alfalfa stands has been shown to reduce potato leafhopper populations and damage (Lamp et al. 1984; Oloumi-Sadeghi et al. 1987, 1989; Lamp 1991). Coggins (1991) examined the potential of intercropping a forage grass with alfalfa to reduce leafhopper damage while still providing a high quality forage. Leafhopper emigration was greater from intercrops of alfalfa and orchardgrass, Dactylis glomerata $\mathrm{L}$., than from alfalfa monocultures (Roda et al. 1997). However, the mechanism(s) leading to this effect was unknown.

Pest abundance and damage can be lower in intercrops than in monocultures (Vandermeer 1989 and references therein). Several mechanisms have been proposed that may decrease pest attraction or presence in intercrops. Root (1973) suggested that a lower concentration of preferred resources in diverse plant mixtures may make a location less favorable to a herbivore or alternately, an increase in enemies may be responsible for decreases in herbivore numbers. Vandermeer (1989) suggested a 3rd mechanism, the trap-crop hypothesis, based 
in part on Trenbath (1976), where another species in the intercrop attracts a pest that is often detrimental to the agronomically more important species. In studies of Empoasca, several mechanisms have been proposed to influence selection of host plants, including changes in microclimate (Lamp 1991), production of volatiles (Poos 1929, Alteri et al. 1977, van Schoonhoven et al. 1981, Smith et al. 1992), and physical barriers (Johnson and Hollwell 1935. Taylor 1956). One or more of these mechanisms may be operating in alfalfa-grass intercrops.

Potato leafhopper adults can survive on $>200$ different plant species (Lamp et al. 1984), and leafhopper numbers can fluctuate widely in a particular habitat (Lamp et al. 1989). When host plants become unsuitable or are removed during cutting, adults migrate to other hosts, including weeds, deciduous trees, and other crop species (Lamp et al. 1989, Flanders and Radcliffe 1989). The development time of nymphs varies among these hosts (Elden and Elgin 1992, Peterson et al. 1992) with monocotyledons such as grasses and sedges being inadequate for $E$. fabae development (Lamp et al. 1994).

A knowledge of leafhopper behavior on different forage grasses may aid in development of alfalfagrass intercrops as a preventative pest management strategy. The objective of the current study was to explore the mechanism(s) leading to increased leafhopper emigration from alfalfa-forage grass intercrops. We evaluated the influence of alfalfa-grass mixtures and plant volatiles on leafhopper emigration in laboratory bioassays. Feeding behavior and residency time of individual leafhoppers placed on alfalfa or grasses were also recorded.

\section{Materials and Methods}

Adult potato leafhoppers were collected from soybeans and reared in a laboratory colony for 8 generations on broad beans, Vicia faba L. To ensure mating, adults were removed from rearing cages daily and held in mixed-sex mating cages with broad beans for $4 \mathrm{~d}$ before use in experiments.

For all experiments, alfalfa ('Big Ten'), smooth bromegrass, Bromus inermis Leyss. ('VNS'), orchardgrass ('Potomac'), and timothy, Phleum pratense L., were planted in 14-cm clay pots at a density of 50 seeds per pot using an automatic seeder (Ames Power Count, Brookings, SD). An alfalfagrass mixture received an application of 25 alfalfa seeds and, on a 1-cm shift of the seed disposition head, a 2nd application of 25 grass seeds. The potting media (Baccto, Michigan Peat, Houston, TX) was adjusted to provide an optimal $\mathrm{pH}$ for alfalfa ( $\mathrm{pH}$ 6.8-7.0) by incorporating $3 \mathrm{~g}$ of pulverized lime into the top $3-4 \mathrm{~cm}^{2}$ of soil. Plants were watered as needed and fertilized weekly with $15 \mathrm{~g}$ of Peters Professional 20:20:20 (Milfpitas, CA) dissolved in 3.8 liters of tap water. Plants were grown in a greenhouse for $6 \mathrm{wk}$. Plants were thinned to
40 plants per pot 1 wk before use. For experiments requiring a single plant, all others were cut $0.5 \mathrm{~cm}$ below the soil with a razor blade and discarded. Test plants were selected based on height (18-20 $\mathrm{cm})$, diameter $(0.2 \mathrm{~cm}$ for alfalfa and smooth bromegrass and $0.3 \mathrm{~cm}$ for orchardgrass), and general vigor.

Experiments were conducted in a chamber $(2 \mathrm{~m}$ wide by $1 \mathrm{~m}$ high by $0.5 \mathrm{~m}$ deep) constructed of white cotton cloth secured over wire shelving. The floor of the chamber was covered with opaque black cloth (cotton/polyester blend). Two florescent light bulbs (Philips cool white, F72T12/CW, Grainger, North Suburban, IL), suspended $0.75 \mathrm{~m}$ above the floor, illuminated the chamber. A 2nd set of lights were located $1 \mathrm{~m}$ away. Daylight (12 h) was simulated by having both lights on, dusk (2 h) and dawn $(2 \mathrm{~h})$ were simulated with only the distant set of lights on, and night $(8 \mathrm{~h})$ no lights on. The temperature ranged from 27 to $28^{\circ} \mathrm{C}$ and from 20 to $45 \% \mathrm{RH}$.

Effect of Forage Grasses on Emigration. Eight treatments were evaluated; alfalfa alone or in combination with smooth bromegrass, orchardgrass or timothy; each grass species alone; and a control with no plants (soil). The experiment was conducted as a randomized complete block design with blocks conducted over time. For each block of the experiment, all treatments (plant species or combinations) were represented each in 1 bioassay arena randomly assigned to a location within the chamber. Emigration behavior was measured using a bioassay arena modified from Coggins (1991) and constructed out of an inverted, colorless 3-liter plastic bottle enclosing the test plants (Fig. 1). Each arena had one 3-cm exit hole offset $3-\mathrm{cm}$ from the top to which was attached a $30-\mathrm{ml}$ colorless plastic diet cup (Fill-Rite, Newark, NJ) with its base removed. Leafhopper movement (walking and flying) resulted in individuals encountering the hole and leaving the arena where they were trapped on the inner surface of a 2nd cup affixed over the lst and coated on its inner surface with Tanglefoot (Tanglefoot, Grand Rapids, MI). For the purpose of our studies, insects captured in the cup were considered to have emigrated. In preliminary experiments, this design allowed nearly all leafhopper to leave the arena within $24 \mathrm{~h}$ when no host plant was present. Conversely, very few individuals left when a preferred host plant was included.

Fifteen mated leafhoppers were gently aspirated into a glass tube, which was subsequently inserted into a hole at the base of arena. Covering the tube with a black paper sheath caused leafhoppers to move into the lighted arena where they fed, rested, oviposited, or emigrated. The outer cup was replaced every $2 \mathrm{~h}$ with a new cup for the first $12 \mathrm{~h}$ of the assay; a final sample was taken at $24 \mathrm{~h}$. The number and sex of the potato leafhoppers trapped at each time were recorded. The experiment was replicated 8 times. Data were analyzed by analysis 


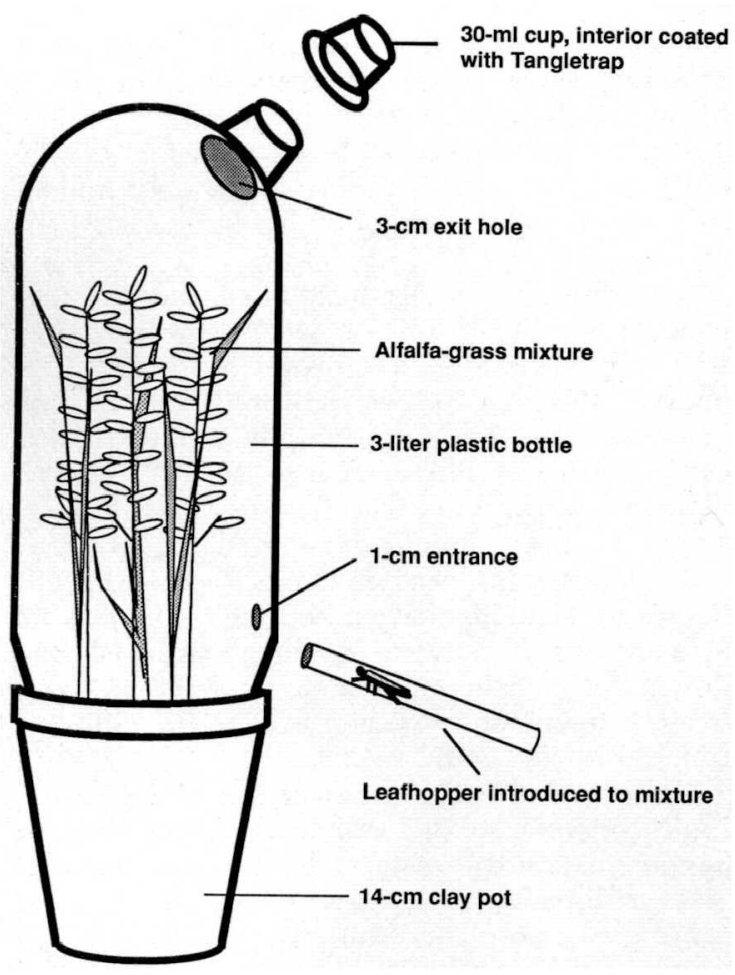

Fig. 1. Bioassay arena used to determine emigration of $E$. fabae from alfalfa, grass, and alfalfa-grass mixtures.

of variance (ANOVA) using the Tukey honestly significant difference (HSD) test with a $P \leq 0.05$ significance level (Wilkinson 1989).

Effect of Noncontact Stimuli on Emigration. A 2 nd set of experiments were conducted to determine how noncontact stimuli (e.g., odors, sight) affected potato leafhopper emigration behavior. In these tests, a barrier, made of $1 \mathrm{~mm}^{2}$ white cotton tent screening supported by $0.05 \mathrm{~cm}^{2}$ wire mesh, bisected the 3-liter bioassay arena. The barrier allowed the exchange of volatiles (confirmed visually using smoke) and did not conceal the visual cues from the adjacent plants. Plants for these experiments were grown as before except grass and alfalfa were planted on opposite halves of the pot.

Treatments included a positive control (alfalfa on both sides), a negative control (soil on both sides), smooth bromegrass separated from alfalfa, and orchardgrass separated from alfalfa. In the 1st experiment, 15 leafhoppers were introduced to the side containing alfalfa to determine if volatiles produced by the grass increased leafhopper emigration. In the 2 nd experiment, 15 leafhoppers were introduced to the side containing the grasses to test if volatiles or the visual presence of alfalfa retained leafhoppers on a forage grass. Each treatment was replicated 6 times. Leafhoppers that emigrated were trapped and data were recorded and analyzed as previously described. Natural logarith- mic transformations of count data were made to satisfy ANOVA assumptions.

Potato Leafhopper Behavior on Alfalfa and Forage Grasses. Differences in female potato leafhopper feeding behavior were determined by observing individuals placed on single alfalfa, smooth bromegrass, or orchardgrass plants. Individual mated females were collected from the rearing cages into 4-ml glass tubes and anesthetized by filling the tube with $\mathrm{CO}_{2}$ for $5 \mathrm{~s}$. After an additional $10 \mathrm{~s}$, insects were placed onto a flat surface. A camel's-hair brush was used to transfer the anesthetized leafhopper onto the main stem or blade $\approx 4-5$ $\mathrm{cm}$ from the base of the plant. Observations began after a 15 -min recovery period. We mounted a dissection microscope (10× oculars, $10 \mathrm{~cm}$ working distance) on a cantilever stand to observe deployment of mouth parts, production of excreta, preening, and movement on the plant. The scope was moved carefully into position so as not to touch or disturb the plant or insect and adjusted to maintain focus as the insect moved. Behaviors were recorded continuously ("all-occurrences" Martin and $\mathrm{Ba}$ teson 1993) for $90 \mathrm{~min}$ or until the insect left the plant. Treatments were single plants of alfalfa, smooth bromegrass, or orchardgrass. Upon completion of the observation, the lst plant was removed and leafhopper behavior on the next species (treatment) was observed.

The experiment was conducted in a randomized complete block design with each of the 11 blocks of the 3 treatments occurring on separate days. Females used for each replication were selected randomly from the holding cage and placed on a predetermined, random ordering of the treatments. Four types of behaviors were recorded: probing, preening, moving, and nonactivity. Leafhopper behavior was defined as probing when its mouth parts were positioned perpendicular to the plant surface and inserted into the plant. Probing was analyzed as probing duration (minutes) and frequency (probes per $90 \mathrm{~min}$ ) as well as total time probing (min per $90 \mathrm{~min}$ ). Proportions of activity (probing, preening, and moving) and nonactivity were based on the total time an individual was on the plant to adjust for insects that did not remain for the entire 90 -min period. Means were analyzed by ANOVA (Abacus Concept 1989) with $\log (x+1)$ or arcsine transformations made as necessary to meet the assumptions of ANOVA. Means were separated after a significant $F$ test using the Tukey HSD means separation test with a $P=0.05$ significance level (Zar 1984).

Residency Time. A bioassay was conducted to measure the length of time potato leafhoppers remained on alfalfa, smooth bromegrass, and orchardgrass. Female leafhoppers taken from holding cages were anesthetized and placed on plants as before. Treatments consisted of single alfalfa, smooth bromegrass, or orchardgrass plants, bare soil moistened with tap water, and a stem mimic. The stem mimic was a hollow glass rod $(12 \mathrm{~cm}$ by 


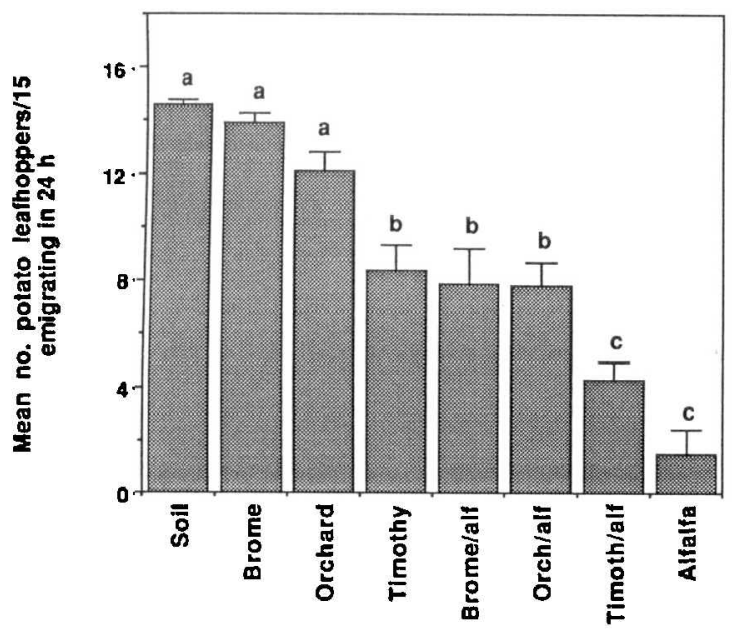

Fig. 2. Mean number of adult potato leafhopper \pm SEM emigrating from soil alone, pure grass or alfalfa, and 1:1 grass/alfalfa mixtures. Treatment effect significant by ANOVA ( $F=22.4 ; \mathrm{df}=7 ; P<0.01)$; means separated by the Tukey HSD test at $P \leq 0.05$.

$4 \mathrm{~mm}$ diameter) coated with oil pigments, Cadmium Yellow, Flake Everwhite No. 2, Windsor Green, and Lamp Black (Windsor and Newton, London) and oven-dried for $3 \mathrm{wk}$ at $100^{\circ} \mathrm{C}$ to remove paint odors (Harris and Miller 1991). Each treatment was enclosed by a 3-liter colorless plastic bottle coated on the inside with Tanglefoot. Leafhoppers leaving a plant, stem mimic, or soil were caught on the inner surface of the bottle cage. Leafhopper locations (on the plant, soil or cage) were recorded every hour for $12 \mathrm{~h}$ and once again at $24 \mathrm{~h}$. There were 10 replications of each treatment; experimental design and analysis were identical to the prior experiment.

\section{Results}

Effect of Forage Grasses on Emigration. Leafhopper emigration was significantly affected by treatment $(F=22.29$, df $=7, P<0.001)$. An average of $97 \%$ of the leafhoppers left the soil-alone within $24 \mathrm{~h}$ (Fig. 2). Mean numbers emigrating from pure-seeded bromegrass and orchardgrass were not significantly different than the soil-alone treatment, indicating the unacceptability of these 2 grasses. Mixtures of alfalfa with orchardgrass or bromegrass resulted in intermediate numbers leaving $(52-53 \%)$ as did timothy alone $(61 \%)$. Alfalfa alone had the lowest mean emigration with only $13 \%$ leaving in $24 \mathrm{~h}$, suggesting a preference for this species. The alfalfa-timothy mixture, which had a mean of $29 \%$ emigration, was not significantly different from pure-seeded alfalfa.

Effect of Noncontact Stimuli on Emigration. The highest emigration (98\%) occurred when leafhoppers were introduced to soil with no adjacent plants (i.e., the negative control [soil:soil, Fig. 3A]).
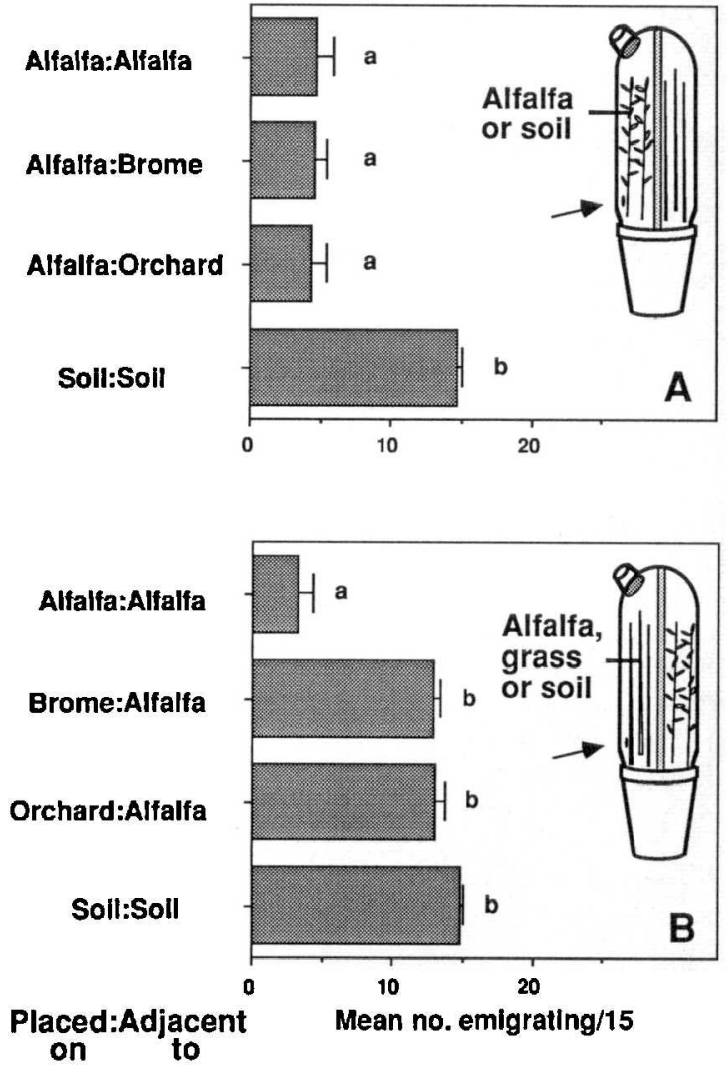

Fig. 3. Mean number of adult potato leafhopper \pm SEM emigrating from divided arenas: $(A)$ leafhoppers placed on alfalfa $(F=37.5, \mathrm{df}=3, P<0.01)$, (B) potato leafhoppers placed on grass $(F=29.3, \mathrm{df}=3, P<0.01$ ) means separated by the Tukey HSD test at $P \leq 0.05$.

Potato leafhopper emigration from alfalfa was low regardless of adjacent plant. Emigration from alfalfa adjacent to orchardgrass $(29 \%)$, smooth bromegrass $(31 \%)$, or alfalfa $(29 \%)$ were all significantly lower than emigration from the negative control. In the 2nd experiment where individuals were placed onto plants or soil adjacent to alfalfa, the negative control again showed the highest level of emigration (99\%), which was not significantly different than emigration from orchardgrass ( $88 \%$ ) or bromegrass (85\%) (Fig. 3B). In contrast, leafhoppers placed on the positive control (alfalfa on both sides) emigrated at significantly lower levels (22\%) than those placed on either grass species or soil.

Potato Leafhopper Behavior on Alfalfa and Forage Grasses. Potato leafhoppers probed each of the plants offered (alfalfa, smooth bromegrass, and orchardgrass). Probing comprised $>91 \%$ of the dynamic behaviors of a female leafhopper on a plant (Table 1). Other active behaviors of preening and walking constituted $<9 \%$ of their activity. All the leafhoppers observed probing plants produced excreta, suggesting ingestion. Although 
Table 1. Mean proportion of time female potato lealhoppers spent probing, preening, moving, or inactive from observations of individual leafhoppers on single plants

\begin{tabular}{|c|c|c|c|c|c|c|c|}
\hline \multirow[b]{2}{*}{ Treatment } & \multicolumn{2}{|c|}{ Probing } & \multicolumn{2}{|c|}{ Preening } & \multicolumn{2}{|c|}{ Walking } & \multirow{2}{*}{$\begin{array}{l}\text { Inactive } \\
\text { Proportion } \\
\text { total time }\end{array}$} \\
\hline & $\begin{array}{l}\text { Proportion } \\
\text { total time }\end{array}$ & $\begin{array}{l}\% \text { Active } \\
\text { behavior }^{b}\end{array}$ & $\begin{array}{l}\text { Proportion } \\
\text { total time }\end{array}$ & $\begin{array}{l}\% \text { Active } \\
\text { behavior }\end{array}$ & $\begin{array}{l}\text { Proportion } \\
\text { total time }\end{array}$ & $\begin{array}{l}\text { \% Active } \\
\text { behavior }\end{array}$ & \\
\hline Alfalfa & $0.38 \mathrm{ab}$ & 92.0 & $0.03 a$ & 7.3 & $0.003 a$ & 0.73 & $0.64 \mathrm{ab}$ \\
\hline Bromegrass & $0.21 \mathrm{a}$ & 90.5 & $0.02 \mathrm{a}$ & 8.6 & $0.002 a$ & 0.86 & $0.77 \mathrm{~b}$ \\
\hline Orchardgrass & $0.50 \mathrm{~b}$ & 95.6 & $0.02 \mathrm{a}$ & 3.8 & $0.003 a$ & 0.57 & $0.53 \mathrm{a}$ \\
\hline
\end{tabular}

Mean proportions followed by the same letter are not significantly different $(P>0.05)$, the Tukey HSD

a Mean calculated by dividing total time of active behavior by total minutes on the plant.

$b$ Proportion of time in particular behavior divided by total of (probing + preening + walking) $\times 100$.

probing comprised the greatest proportion of activity, leafhoppers were motionless for most of their tenure on the plant (Table 1). Leafhoppers on smooth bromegrass were inactive $77 \%$ of the time, probing only $21 \%$ of their time on the plant. Potato leafhoppers placed on orchardgrass were inactive $53 \%$ of the time but probed $50 \%$ of their time on the plant. On alfalfa, leafhoppers were inactive $64 \%$ and probed $38 \%$ of the time.

Although the frequency of probes females made did not differ between plant species $(F=1.83$, df $=2, P=0.18$, Fig. 4 A), the total time spent probing $(F=5.20, \mathrm{df}=2, P=0.011$, Fig. 4B $)$ and the duration of a single probe $(F=6.34, \mathrm{df}=2, P=$ 0.005 , Fig. $4 \mathrm{C}$ ) varied significantly across plants. Mean probing duration (total in $90 \mathrm{~min}$ ) was longer on orchardgrass $(42.1 \pm 5.6 \mathrm{~min})$ than on alfalfa $(34.0 \pm 5.3 \mathrm{~min})$. On smooth bromegrass, leafhoppers probed an average of only $17.8 \pm 5.4$ min, a significantly shorter duration than those placed on orchardgrass or alfalfa. An individual probe on orchardgrass lasted $12.8 \pm 3.2 \mathrm{~min}$. In contrast, probes on alfalfa and smooth bromegrass lasted only $4.2 \pm 1.0$ and $3.5 \pm 1.0 \mathrm{~min}$, respectively. This combined with the observed production of excreta suggested that the grasses served as a food or water source.

Residency Time. The time potato leafhoppers remained on a plant varied significantly $(F=6.57$, $\mathrm{df}=4, P<0.001)$. They remained the longest on alfalfa ( $x=10.7 \pm 0.9 \mathrm{~h}$, Fig. 5), followed by bromegrass $(x=7.5 \pm 1.4 \mathrm{~h})$ and orchardgrass $(x$ $=5.9 \pm 1.3 \mathrm{~h}$ ). Residency time on the 2 grasses did not differ statistically; however, time on orchardgrass was significantly less than on alfalfa. Leafhoppers were observed actively probing the forage grasses with patterns of probing, walking, and preening similar to those described above.

Leafhoppers also remained for appreciable periods on bare soil $(x=3.0 \pm 0.8 \mathrm{~h})$ and the stem mimic $(x=5.3 \pm 1.0 \mathrm{~h}$ ) despite the lack of food resources (Fig. 5). On both of these treatments, leafhoppers probed the soil. Those placed on the mimic occasionally walked off, probed the soil, and returned. With the added feature of a vertical green stem, leafhoppers remained $2.3 \mathrm{~h}$ longer on the mimic than in its absence.

\section{Discussion}

Some herbivores move more frequently in polycultures that contain nonpreferred hosts than in monocultures (Risch 1980). Orchardgrass or smooth bromegrass combined with alfalfa increased the movement of leafhoppers in the bioassay arenas and resulted in increased emigration rates. These laboratory experiments support results from field trials where alfalfa intercropped with the same grass species showed reductions in potato leafhopper numbers (Roda et al. 1997). In other studies with Empoasca, increased activity occurred in the presence of preferred hosts as densities of nonpreferred hosts increased (Alteri et al. 1977; Smith et al. 1992, 1994; Roltsch and Gage 1990). Smith et al. (1994) found that potato leafhopper activity in the presence of crabgrass was 2- to 4-fold greater than alfalfa alone under equivalent vegetation density. Leafhopper activity also increased as crabgrass concentration increased compared with equivalent alfalfa densities.

In our experiments, grass volatiles alone did not induce leafhopper emigration. Rather, physical contact with a grass was required to elicit emigration. Olfactory stimuli from nonhost plants can in some cases repel or deter specialist insects (Tahvanainen and Root 1972); however, such cues may have variable effects on polyphagous insects (Andow 1991). In our laboratory experiments, $>59 \%$ more potato leafhoppers left the arena when they physically encountered orchardgrass and $>54 \%$ more emigrated when in contact with bromegrass compared with leafhoppers placed on alfalfa adjacent to each grass. Similarly, whole plant volatiles produced by alfalfa or its visual presence did not arrest or prevent potato leafhopper movement from nonpreferred hosts. Our results vary from the suggestion of Smith et al. (1994) that olfactory cues from crabgrass lowered $E$. fabae residence time on alfalfa adjacent to grass.

In alfalfa-grass intercrops, long residency times and probing on forage grasses may divert a substantial portion of leafhopper feeding time away from alfalfa. Our behavior observations showed that potato leafhopper will probe all plant species tested for extended periods. Roltsch and Gage (1990) found that potato leafhoppers spent long 

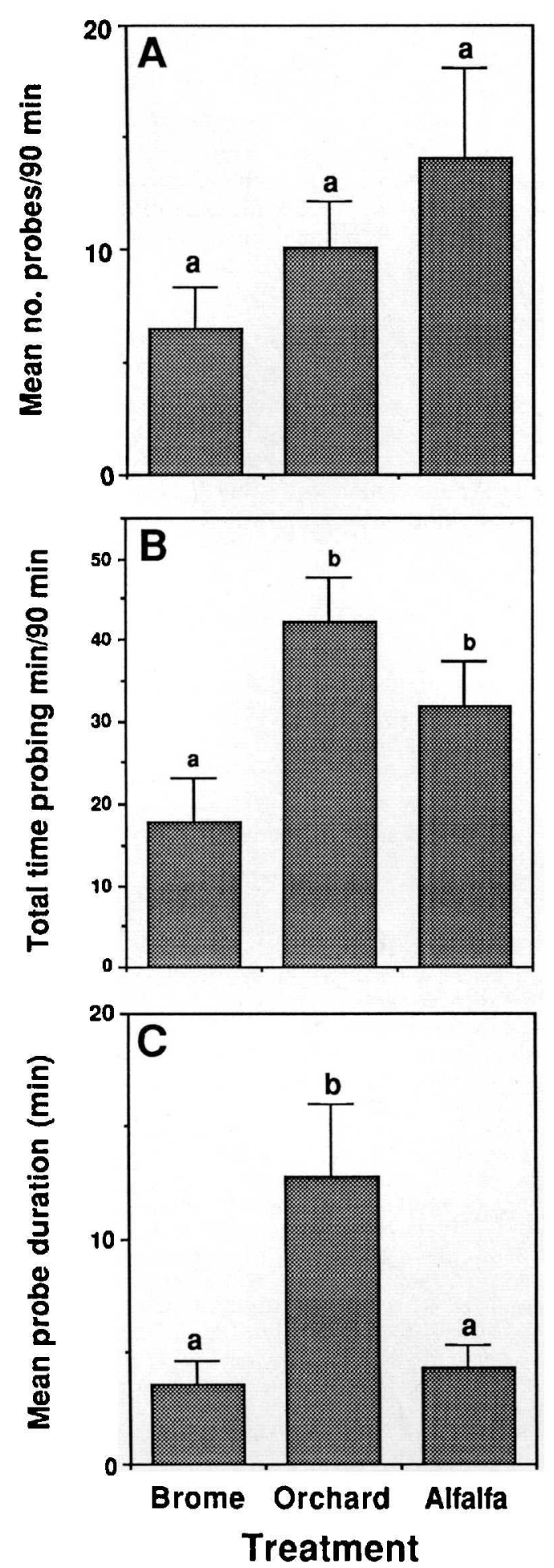

Fig. 4. (A) Mean frequency of probes \pm SEM by female leafhoppers $(F=1.83$, $\mathrm{df}=2, P<0.18)$, (B) the total minutes $\pm \mathrm{SEM}$ females probed $(F=5.20, \mathrm{df}=2$, $P<0.011$ ), and (C) the length of time \pm SEM females sustained a single probe on smooth bromegrass, orchardgrass and alfalfa $(F=6.34$, $\mathrm{df}=2, P<0.005)$ means separated by the Tukey HSD test at $P \leq 0.05$.

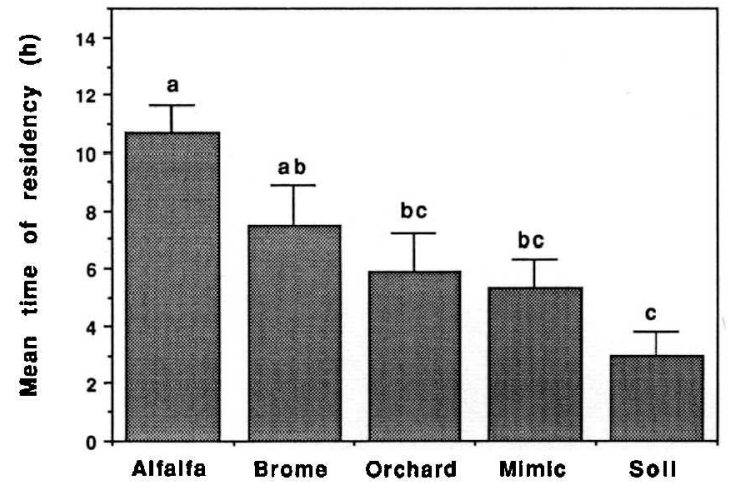

Fig. 5. Mean residency time of female leafhoppers \pm SEM placed on a single alfalfa, smooth bromegrass or orchardgrass plant, a stem mimic, and soil $(F=6.57$, df $=4, P<0.001)$ means separated by the Tukey HSD test at $P \leq 0.05$.

periods on tomato plants, which resulted in less feeding (measured by amounts of honeydew collected) in cages containing bean and tomato leaves compared with those containing only bean leaves. Studies of potato leafhopper behavior on crabgrass, Digitaria sanguinalis (L.), showed a similar residency pattern (Smith et al. 1992, 1994). Leafhoppers were observed resting on the grass before increases in movement (measured by flights per minute) occurred (Smith et al. 1994).

Indiscriminate probing of host and nonhost plants has been documented previously with other Empoasca species. In laboratory experiments, Saxena and Saxena (1974) found that $E$. devastans Distant probed a variety of surfaces regardless (e.g., glass, muslin, parafilm), suggesting that a chemical stimulus was not necessary to induce a probe. Saxena et al. (1974) found that $E$. devastans and $E$. kerri motti Phuthi probed host and nonhost plants with equal frequency. In their study, these insects did not discriminate or show preferences for any of the test plants. However, they ingested different quantities of food from each of the species.

Although leafhoppers will probe a forage grass for extended periods, they emigrate from the grasses sooner than from alfalfa. Increased movement from forage grasses may occur because of the ability of a female to accept hosts that can best support nymphal development. Although adult potato leafhoppers can survive on monocots, they are not known to produce nymphs thereon (Lamp et al. 1994). Information about nutritional quality of a host, obtained when feeding on a monocot, may contribute to female leafhoppers acceptance of hosts for oviposition. In laboratory experiments with $E$. devastans and $E$. kerri motti, plants varied in nutritive values and suitability for the growth, survival, egg-production, and oviposition (Saxena and Saxena 1974). Studies of potato leafhopper development on birdsfoot trefoil, Lotus corniculatus, 
and red clover, Trifolium pratense, suggest that potato leafhoppers discriminated against plants that support lower rates of nymphal development (Peterson et al. 1992). Resistant plant varieties yielding poor nymphal development and survival are less acceptable for feeding and oviposition (Tingey 1985, Elden and Elgin 1992). In studies by Smith et al. (1992), potato leafhoppers preferred to oviposit on and reside on pure alfalfa over alfalfa mixed with crabgrass.

Inability to access acceptable plant tissues may also have caused potato leafhoppers to leave the forage grasses. Trichomes present on smooth bromegrass in our study appeared to hinder potato leafhopper probing. Pubescence is the best known characteristic associated with plant resistance to leafhoppers (Poos 1929, Johnson and Hollwell 1935, Taylor 1956). Trichomes appear to create a mechanical barrier, limiting access to preferred feeding sites as well as hindering locomotion and attachment to the host plant (Tingey 1985). Taylor (1956) observed that the amount of hopperburn on alfalfa was correlated inversely with density of trichomes.

The morphology of the grass blade may also be a factor reducing the time leafhoppers spent on grasses. Smith and Poos (1931) reported potato leafhoppers made "exploratory" punctures in the vicinity of the vascular bundles of the main and lateral veins of the leaflet and sometimes pierced the epidermis on the opposite side of the leaf. We observed probes lasting 3-5 min in which the leafhoppers stylets completely penetrated a grass blade and emerged on the other side. Leafhoppers making several such probes on blades without ingestion may depart.

Our studies indicated that leafhopper feeding behavior and residence time are different on a grass versus alfalfa. Although leafhoppers probed for long periods on the grasses they also left the grasses earlier than did individuals on alfalfa. Combined with prior laboratory bioassays and field experiments (Coggins 1991, Roda et al. 1997), we propose a model explaining observed reductions in potato leafhopper density and damage in alfalfagrass intercrops. As leafhoppers alight within a stand, contact with a given plant is contingent upon its leaf surface area and distribution. Leafhoppers contact a given plant then probe to determine suitability. Contact with a forage grass results in several hours of feeding followed by movement to another plant. We propose that repeated encounters with a grass not only diverts feeding from alfalfa but also leads to increased movement within the stand, some proportion of which results in emigration from the field. Thus, increasing the frequency of contact with a forage grass leads to lower levels of feeding on alfalfa and higher levels of emigration, reducing potato leafhopper feeding injury to alfalfa and recruitment.

Knowledge of these behaviors can have practical application to forage production systems. Manage- ment of potato leafhoppers in alfalfa production depends primarily on the therapeutic practices of cutting and pesticide application (Manglitz and Ratcliffe 1988). Routine inspection and early detection are essential to determine need for intervention (Cuperus et al. 1983, Lamp et al. 1985). However, leafhopper populations often grow undetected until economic thresholds are surpassed. Intercropping orchardgrass or smooth bromegrass with alfalfa may reduce the need for chemical or mechanical control of $E$. fabae as well as other pests (Roda et al. 1996). However, further research is needed regarding how repeated contacts with a forage grass affects movement within fields and whether increased activity leads to overall emigration from the field. Field studies are also needed to determine which grass species cause the greatest reduction in potato leafhopper numbers and injury.

\section{Acknowledgments}

We thank M. Haas, C. Fink, and H. Martin for help in insect rearing and collection of these data. This work was funded in part by USDA NC3-IPM grant 93-34103-8471 to O. B. Hesterman, D.A.L., and J. J. Kells.

\section{References Cited}

Abacus Concepts. 1989. SuperANOVA. Abacus Concepts, Berkeley, CA.

Altieri, M. A., A. van Schoonhoven, and J. Doll. 1977. The ecological role of weeds in insect pest management systems: a review illustrated by bean (Phaseolus vulgaris) cropping systems. PANS (Pest Artic. News Summ.) 23: 195-205.

Andow, D. A. 1991. Vegetational diversity and arthropod population response. Annu. Rev. Entomol. 36: $561-586$.

Backus, E. A., and W. B. Hunter. 1989. Comparison of feeding behavior of the potato leafhopper Empoasca fabae (Homoptera: Cicadellidae) on alfalfa and broad bean leaves. Environ. Entomol. 18: 473-480.

Ball. E. D. 1919. The potato leafhopper and its relation to the hopper burn. J. Econ. Entomol. 12: 149155.

Barnes, D. K., and C. C. Shaeffer. 1985. Alfalfa, pp. 89-97. In M. E. Heath, D. F. Barnes, and D. S. Metcalfe [eds.], Forages. The science of grassland agriculture. Iowa State University Press, Ames.

Byers, R. A., J. W. Neal, J. H. Elgin, K. R. Hill, J. E. MeMurtrey, and J. Feldmesser. 1977. Systemic insecticides with spring-seeded alfalfa for control of potato leafhopper. J. Econ. Entomol. 70: 337-340.

Carlson, J. D., M. E. Whalon, D. A. Landis, and S. H. Gage. 1991. Evidence for long-range transport of potato leafhopper into Michigan. pp. 123-127. In Proceedings 10th Conference on Biometeorology and Aerobiology and the Special Session on Hydrometeorology, 10-13 September 1991, American Meteorological Society, Boston, MA.

Coggins, M. L. 1991. Potato leafhopper (Empoasca fabae) and alfalfa weevil (Hypera postica) density and damage in alfalfa-forage grass binary mixtures. M.S. thesis, Michigan State University, East Lansing. 
Cuperus, G. W., E. B. Radcliffe, D. K. Barnes, and G. C. Marten. 1983. Economic injury levels and economic thresholds for potato leafhopper (Homoptera: Cicadellidae) on alfalfa in Minnesota. J. Econ. Entomol. 76: 1341-1349.

Elden, T. C., and J. H. Elgin. 1992. Mechanisms of resistance to the potato leafhopper (Homoptera: $\mathrm{Ci}$ cadellidae) in selected alfalfa clones. J. Econ. Entomol. 85: 576-582.

Faris, M. A., H. Baenziger, and P. P. Terhune. 1981. Studies on potato leafhopper (Empoasca fabae) damage in alfalfa. Can. J. Plant Sci. 61: 625-632.

Flanders, K. L., and E. B. Radcliffe. 1989. Origins of potato leafhoppers (Homoptera: Cicadellidae) invading potato and snap bean in Minnesota. Environ. Entomol. 18: 1015-1024.

Harris, M. O., and J. R. Miller. 1991. Quantitative analysis of ovipositional behavior: effects of a hostplant chemical on the onion fly (Diptera: Anthomyiidae). J. Insect Behavior 4: 773-792.

Hower, A. A., and P. W. Flinn. 1986. Effects of feeding by potato leafhopper nymphs (Homoptera: Cicadellidae) on growth and quality of established stand alfalfa. J. Econ. Entomol. 79: 779-784.

Hunter W. B., and E. A. Backus. 1989. Mesophyllfeeding by the potato leafhopper, Empoasca fabae (Homoptera: Cicadellidae): results from electronic monitoring and thin-layer chromatography. Environ. Entomol. 18: 465-471.

Hutchins, S. H., and L. P. Pedigo. 1990. Phenological disruption and economic consequence of injury to alfalfa induced by potato leafhopper (Homoptera: $\mathrm{Ci}$ cadellidae). J. Econ. Entomol. 83: 1587-1594.

Johnson, H. W., and E. A. Hollwell. 1935. Pubescent and glabrous characters of soybeans as related to resistance to injury by the potato leafhopper. J. Agric. Res. 51: $371-381$

Kindler, S. D., W. R. Kehr, R. L. Ogden, and J. M. Schalk. 1973. Effect of potato leafhopper injury on yield and quality of resistant and susceptible alfalfa clones. J. Econ. Entomol. 55: 462-465.

Lamp, W. O. 1991. Reduced Empoasca fabae (Homoptera: Cicadellidae) density in oat-alfalfa intercrop systems. Environ. Entomol. 20: 118-126.

Lamp, W. O., R. J. Barney, E. J. Armbrust, and G. G. Kapusta. 1984. Selective weed control in springplanted alfalfa: effect on leafhoppers and planthoppers (Homoptera: Auchenorrhyncha), with emphasis on potato leafhopper. Environ. Entomol. 13: 207-213.

Lamp, W. O., S. J. Roberts, E. J. Armbrust, and K. L. Steffey. 1985. Impact of insecticide applications at various alfalfa growth stages on potato leafhoppers and planthoppers (Homoptera: Auchenorrhyncha), with emphasis on potato leafhopper. Environ. Entomol. 13: 207-213.

Lamp, w. O., M. J. Morris, and E. J. Armbrust. 1989. Empoasca (Homoptera: Cicadellidae) abundance and species composition in habitats proximate to alfalfa. Environ. Entomol. 18: 423-428.

Lamp, W. O., G. R. Nielsen, and S. D. Danielson. 1994. Patterns among host plants of potato leafhopper, Empoasca fabae (Homoptera: Cicadellidae). J. Kans. Entomol. Soc. 67: 354-368.

Manglitz, G. R., and R. H. Ratcliffe, 1988. Insects and mites, pp. 671-699, In Alfalfa and alfalfa improvement-agronomy monograph no. 29. American Society of Agranomy, Madison, WI.
Martin P., and P. Bateson. 1993. Measuring behavior: an introductory guide, 2nd ed. Cambridge University Press, New York.

Nielsen G. R., W. O. Lamp, and G. W. Stutte. 1990. Potato leafhopper (Homoptera: Cicadellidae) feeding disruption of phloem translocation in alfalfa. J. Econ. Entomol. 83: 807-813.

Oloumi-Sadeghi, H., L. R. Zavaleta, W. O. Lamp, E. J. Armbrust, and G. Kapusta. 1987. Interactions of the potato leafhopper (Homoptera: Cicadellidae) with weeds in an alfalfa ecosystem. Environ. Entomol. 16: 1175-1180.

Oloumi-Sadeghi, H., L. R. Zavaleta, G. Kapusta, W. O. Lamp, and E. J. Ambrust. 1989. Effects of potato leafhopper (Homoptera: Cicadellidae) and weed control on alfalfa yield and quality. J. Econ. Entomol. 82: 923-931.

Peterson, S. S., J. L. Wedberg, and D. B. Hogg. 1992. Survival, development and population dynamics of Empoasca fabae (Homoptera: Cicadellidae), on three legume hosts. Gt. Lakes Entomol. 25: 9-14.

Poos, F. W. 1929. Leafhopper injury to legumes. J Econ. Entomol. 22: 146-153.

Risch, S. 1980. The population dynamics of several herbivorous beetles in a tropical agroecosystem: the effect of intercropping corn, beans and squash in Costa Rica. J. App. Ecol. 17: 593-612.

Roda, A. L., D. A. Landis, M. L. Coggins, E. Spandl, and 0 . B. Hesterman. 1996. Forage grasses decrease alfalfa weevil (Coleoptera: Curculionidae) damage and larval numbers in alfalfa-grass intercrops. J. Econ. Entomol. 89: 743-750.

Roda, A. L., D. A. Landis, and M. L. Coggins. 1997. Forage grasses elicit emigration of adult potato leafhopper (Homoptera: Cicadellidae) from alfalfa-grass mixtures. Environ. Entomol. 26: 745-753.

Roltsch, W. J., and S. H. Guge. 1990. Potato leafhopper (Homoptera: Cicadellidae) movement, oviposition, and feeding response patterns in relation to host and nonhost vegetation. Environ. Entomol. 19: 524-533.

Root, R. 1973. Organization of a plant-arthropod association in simple and diverse habitats: the fauna of collards (Brassica oleracea). Ecol. Monogr. 43: 95124.

Saxena, K. N., and R. C. Saxena. 1974. Pattems of relationship between certain leafhoppers and plants: part II. Role of sensory stimuli in orientation and feeding. Entomol. Exp. Appl. 17: 493-503.

Saxena, K. N., J. R. Gandhi, and R. C. Saxena. 1974. Patterns of relationship between certain leafhoppers and plants: part I. Responses to plants. Entomol. Exp. Appl. 17: 303-318.

van Schoonhoven, A., C. Cardona, J. Garcia, and F. Garzon. 1981. Effect of weed cover on Empoasca krameri (Ross and Moore) populations and dry bean yields. Environ. Entomol. 10: 901-907.

Smith, L. M., W. O. Lamp, and E, J. Armbrust. 1992. Potato leafhopper (Homoptera: Cicadellidae) utilization of alfalfa as host: The role of non-host stimuli. J. Entomol. Sci. 27: 56-64.

1994. Behavioral and reproductive response of caged Empoasca fabae (Homoptera: Cicadellidae) to vegetation density of a host legume and a non-host grass. J. Entomol. Sci. 29: 66-81.

Tahvanainen J. O., and R. B. Root. 1972. The influence of vegetational diversity on the population ecology of a specialized herbivore, Phyllotreta cruciferae 
(Coleoptera: Chrysomelidae). Oecologia (Berl.) 10: $321-346$.

Taylor, N. L. 1956. Pubescence inheritance and leafhopper resistance relationships in alfalfa. Agron. J. 48: $78-81$.

Taylor, P. S., and E. J. Shields. 1995. Development of migrant source of populations of the potato leafhopper (Homoptera: Cicadellidae). Environ. Entomol. 24: 1115-1121.

Tingey, W. M. 1985. Plant defensive mechanisms against leathoppers. pp. 217-234. In L. R. Nault and J. G. Rodriquez [eds.], The leafhoppers and planthoppers. Wiley, New York.
Trenbath, B. R. 1976. Plant interactions in mixed crop communities. pp. 129-170. In R. I. Papendick, P. A. Sanchez, and G. B. Triplett [eds.], Multiple cropping. ASA special publication no. 27. American Society of Agronomy, Madison, WI.

Vandermeer, J. 1989. The ecology of intercropping Cambridge University Press, Cambridge.

Wilkinson, L. 1989. SYSTAT: the system for statistics. SYSTAT, Evanston, IL.

Zar, J. H. 1984. Biostatistical analysis, 2nd ed. Prentice-Hall, Englewood Cliffs, NJ.

Received for publication 26 February 1996; accepted 28 March 1997. 